\title{
OPTIMASI PH AWAL DAN PENAMBAHAN ELEKTROLIT GARAM DALAM PENGOLAHAN LIMBAH SURFAKTAN SECARA ELEKTROKOAGULASI
}

\author{
Yusbarina \\ Program Studi Pendidikan Kimia, Fakultas Tarbiyah dan Keguruan, \\ Universitas Islam Negeri Sultan Syarif Kasim Riau, Indonesia
}

Email: yusbarina_7@yahoo.com

ABSTRAK

Elektrokoagulasi adalah salah satu metode yang banyak digunakan untuk mengolah air limbah. Keefektifannya sangat dipengaruhi oleh parameter operasional. Oleh karena itu, tujuan dari penelitian ini adalah untuk optimasi parameter operasional yaitu $\mathrm{pH}$ awal dan penambahan elektrolit garam dalam pengolahan limbah surfaktan secara elektrokoagulasi. Elektrokoagulasi dilakukan dengan sistem batch dengan menggunakan limbah simulasi sodium dodesil sulfat (SDS) pada kondisi operasional: konsentrasi SDS $200 \mathrm{mgL}^{-1}$, kerapatan arus $50 \mathrm{~A} / \mathrm{m}^{2}$ dan waktu elektrolisis 60 menit. Aluminium digunakan sebagai bahan elektroda. Variasi $\mathrm{pH}$ awal yang dilakukan adalah 2, 4, 6, 8 dan 10. Variasi elektrolit adalah $\mathrm{NaCl}$, $\mathrm{Na}_{2} \mathrm{SO}_{4}$, dan tanpa penambahan elektrolit garam. Pengolahan limbah surfaktan dengan elektrokoagulasi efektif pada $\mathrm{pH}$ awal 4 dan tanpa penambahan elektrolit garam dengan \% penurunan kadar surfaktan sebesar $94,04 \%$.

Kata kunci: elektrokoagulasi, surfaktan anionik, $\mathrm{pH}$, elektrolit.

\section{PENDAHULUAN}

Surfaktan digunakan secara luas dalam berbagai industri dan kegiatan rumah tangga karena kemampuannya menurunkan tegangan antar muka fluida. Penggunaan surfaktan meningkat dari hari ke hari. Sekitar satu juta ton surfaktan diproduksi setiap tahun di dunia dan $70 \%$ diantaranya adalah surfaktan anionik. Berbagai industri seperti industri deterjen, produk kebersihan dan kecantikan menggunakan surfaktan anionik sebagai bahan baku utama. Oleh karena itu dibutuhkan satu metode yang handal dan ekonomis untuk mengolah limbahnya sebelum dibuang atau dilepas ke sumber air. Berdasarkan keputusan menteri lingkungan hidup nomor 03 tahun 2010, tentang baku mutu air limbah bagi kawasan industri, kadar maksimum MBAS dalam air limbah adalah $10 \mathrm{mg} / \mathrm{L}$.

Elektrokoagulasi adalah salah satu metode yang banyak digunakan untuk mengolah air limbah. Efektivitasnya yang tinggi, alat yang sederhana, mudah dioperasikan serta efluen yang dihasilkan jernih, tidak berwarna, dan tidak berbau, mudah dipisahkan secara cepat dengan filtrasi dan tidak memerlukan bahan kimia, sehingga tidak membutuhkan kemungkinan pengolahan berikutnya, menjadi alasan utama pemilihan metode ini.

Elektrokoagulasi telah banyak digunakan untuk mengolah berbagai jenis limbah, diantaranya penghilangan warna pada limbah pabrik teh (Maghanga, J.K dkk, 2009), pengolahan limbah tekstil (Kobya, M dkk, 2003), pengolahan limbah zat warna (Mollah, M.Y.A dkk, 2010, Alaton, I.A dkk 2008, Kashefialasl, M $\mathrm{dkk}, 2006$ ), pemurnian air laut (Timmes, T.C, 2009), penghilangan hidrokuinon dari air (Prabhakari, D dkk, 2010), dan penghilangan logam - logam berat di perairan (Vasudevan, S, 2009).

Keefektifan elektrokoagulasi sangat dipengaruhi oleh parameter operasional, yaitu $\mathrm{pH}$ awal, penambahan elektrolit garam, kerapatan arus, waktu elektrolisis dan konsentrasi awal 
surfaktan anionik. Pada penelitian ini, parameter yang dioptimasi adalah $\mathrm{pH}$ awal dan penambahan elektrolit garam.

Pengaturan $\mathrm{pH}$ sangat penting dalam proses elektrokoagulasi. Variasi $\mathrm{pH}$ dilakukan untuk mendapatkan \% penurunan kadar surfaktan yang tinggi dengan kadar aluminium yang rendah dalam larutan. $\mathrm{pH}$ sangat menentukan spesi aluminium yang terbentuk pada oksidasi aluminium di anoda.

Penambahan elektrolit garam bertujuan untuk meningkatkan konduktivitas larutan, sehingga dapat menghemat konsumsi energi. Selain itu elektrolit dapat memperkecil kelarutan sehingga mempercepat proses koagulasi.

\section{METODOLOGI PENELITIAN}

Alat

Alat yang digunakan pada penelitian ini adalah peralatan gelas yang lazim digunakan di laboratorium penelitian kimia analitik, sumber arus listrik searah, voltmeter (multimeter), amperemeter (multimeter), $\mathrm{pH}$-meter, konduktometer, pengaduk magnetik, batang pengaduk magnetik, neraca analitis Mettler AE 200, spektrofotometer UV-Vis Agilent, spektrofotometer serapan atom SpectrAA (PPPGL-Bandung).

\section{Bahan}

Bahan yang digunakan pada penelitian ini adalah sodium dodesil sulfat (SDS), lempeng aluminium (95,6\%), aquades, indikator fenolftalin, $\mathrm{NaOH}, \mathrm{H}_{2} \mathrm{SO}_{4(\mathrm{p})}$, Metilen biru, $\mathrm{CHCl}_{3}$ p.a., $\mathrm{HCl}_{(\mathrm{p})}, \mathrm{HNO}_{3(\mathrm{p})}, \mathrm{Al}_{2} \mathrm{O}_{3}$.

\section{Prosedur Kerja}

\section{Reaktor}

Pengoperasian dilakukan dengan sistem batch. Reaktor elektrokoagulasi yang digunakan berkapasitas $500 \mathrm{~mL}$ yang dilengkapi dengan peralatan stirrer untuk mengaduk larutan agar konsentrasi koagulan menjadi homogen. Elektroda yang digunakan sebagai anoda dan katoda adalah ukuran $4 \mathrm{~cm} \times 7 \mathrm{~cm}$ sebanyak dua buah. Luas permukaan elektroda anoda pada penelitian ini adalah $0.0028 \mathrm{~m}^{2}$ sehingga diperoleh rasio luas permukaan elektroda anoda terhadap volume reaktor sebesar $5.6 \mathrm{~m}^{2} / \mathrm{m}^{3}$. plat aluminium $(95,6 \%)$ dengan Jarak antar elektroda adalah $9 \mathrm{~mm}$. Pada Penelitian ini semua elektroda dihubungkan dengan arus listrik yang berasal dari arus DC, yaitu satu elektroda dihubungkan dengan kutub positif yaitu anoda dan satu elektroda dengan kutub negatif yaitu katoda.

\section{Optimasi pH awal elektrokoagulasi}

Untuk mengoptimasi $\mathrm{pH}$ awal dilakukan variasi pada $\mathrm{pH} 2,4,5,6,8$, dan 10 dengan parameter yang lain dibuat tetap yaitu konsentrasi SDS $=200 \mathrm{mg} / \mathrm{L}$, penambahan elektrolit $\mathrm{NaCl}$, kerapatan arus $50 \mathrm{~A} / \mathrm{m}^{2}$ dan waktu elektrolisis 60 menit. Kemudian dimonitor penurunan kadar SDS dengan spektrofotometer secara biru metilen, dan dimonitor kadar aluminium di dalam larutan dengan spektrofotometer serapan atom.

\section{Optimasi penambahan elektrolit garam}

Untuk mengetahui pengaruh elektrolit garam maka dilakukan variasi tanpa penambahan elektrolit garam, penambahan elektrolit $\mathrm{NaCl}$, dan penambahan elektrolit $\mathrm{Na}_{2} \mathrm{SO}_{4}$ dengan parameter yang lain dibuat tetap yaitu konsentrasi $\mathrm{SDS}=200 \mathrm{mg} / \mathrm{L}$, pH awal 4, kerapatan arus 50 $\mathrm{A} / \mathrm{m}^{2}$ dan waktu elektrolisis 60 menit. Penambahan elektrolit $\mathrm{NaCl}$ dan $\mathrm{Na}_{2} \mathrm{SO}_{4}$ dilakukan pada total ionik yang sama di dalam larutan yaitu $1.7 \times 10^{-2} \mathrm{M}$. Kemudian dimonitor penurunan kadar SDS dengan spektrofotometer secara biru metilen.

\section{Pengujian surfaktan anionik}

Pada penelitian ini monitoring kadar surfaktan anionik dilakukan dengan spektrofotometer secara biru metilen yang mengacu pada SNI 06-6989.51-2005. Prinsip utama metode pengujian ini adalah surfaktan anionik akan bereaksi dengan metilen biru membentuk pasangan ion berwarna biru yang larut dalam pelarut organik. Intensitas warna biru yang terbentuk diukur dengan spektrofotometer pada panjang gelombang $652 \mathrm{~nm}$. Serapan yang diukur setara dengan kadar surfaktan anionik.

\section{Pengukuran kadar aluminium di larutan}

Sebagai agen koagulan, ion aluminium yang terlepas dari elektroda akibat proses elektrokimia diukur nilainya. Untuk mengukur konsentrasi aluminium yang terlepas ke dalam larutan dilakukan dengan spektrofotometer serapan atom (SSA) dimana metode pengukurannya mengacu pada SNI 06-6989.34-2005 sehingga diperoleh 
nilai konsentrasi aluminium total. Prinsip utama dari metode ini adalah sampel yang akan diuji ditambahkan dengan asam klorida. Kemudian sampel tersebut dipanaskan yang bertujuan untuk melarutkan analit aluminium(III) dan menghilangkan zat-zat penganggu, dan selanjutnya diukur serapannya dengan SSA.

\section{HASIL DAN PEMBAHASAN}

\section{Optimasi pH terhadap efektivitas} elektrokoagulasi surfaktan anionik

Tabel. 1. Hasil \% penurunan kadar surfaktan pada variasi $\mathrm{pH}$ awal

\begin{tabular}{cccccc}
\hline \multirow{2}{*}{ awal } & $\mathrm{pH}$ & \multicolumn{2}{c}{ MBAS $(\mathrm{mg} / \mathrm{L})$} & \% penurunan kadar & $\begin{array}{c}\text { Kadar aluminium } \\
\text { (mg/L) }\end{array}$ \\
\hline 2 & akhir & awal & akhir & SDS & 84,92 \\
4 & 4 & 200 & 22,89 & 88,55 & 16,22 \\
6 & 6 & 200 & 23,68 & 88,15 & 11,46 \\
8 & 7 & 200 & 88,89 & 55,55 & 17,13 \\
10 & 9 & 200 & 90,56 & 54,72 & 42,53 \\
\hline
\end{tabular}

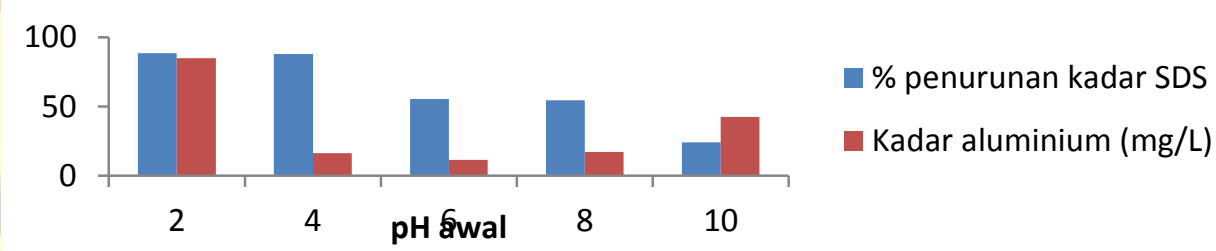

Gambar. 1. Pengaruh $\mathrm{pH}$ awal terhadap \% penurunan kadar surfaktan anionik SDS. (Kondisi operasional: konsentrasi SDS $200 \mathrm{mgL}-1$, penambahan elektrolit $\mathrm{NaCl}$, waktu elektrolisis 60 menit, kerapatan arus $\left.50 \mathrm{~A} / \mathrm{m}^{2}\right)$

$\mathrm{pH}$ awal 4 merupakan $\mathrm{pH}$ yang optimum untuk melakukan pengolahan limbah surfaktan dengan elektrokoagulasi. Pada daerah asam \% penurunan kadar surfaktan SDS tinggi dan menurun pada daerah basa. Hal ini disebabkan pada $\mathrm{pH}$ yang rendah, elektroda logam menjadi lebih tidak stabil dan lebih reaktif, sehingga menghasilkan lebih banyak ion di larutan dan meningkatkan pelarutan logam dalam larutan (Ankit Mohta, 2007). Menurut Mollah dkk (2001), Elektrolisis anoda aluminium menghasilkan spesi monomerik kationik seperti $\mathrm{Al}^{3+}$ dan $\mathrm{Al}(\mathrm{OH})_{2}{ }^{+}$pada $\mathrm{pH}$ rendah, yang selanjutnya pada $\mathrm{pH}$ yang sesuai akan berubah menjadi $\mathrm{Al}(\mathrm{OH})_{3}$ pada awalnya dan akhirnya terbentuk polimer $\mathrm{Al}_{\mathrm{n}}(\mathrm{OH})_{3 \mathrm{n}}$ sesuai dengan reaksi berikut:

$$
\begin{aligned}
& \mathrm{Al} \rightarrow \mathrm{Al}^{3+}+3 \mathrm{e}^{-} \\
& \mathrm{Al}^{3+}+3 \mathrm{H}_{2} \mathrm{O} \rightarrow \mathrm{Al}(\mathrm{OH})_{3}+3 \mathrm{H}^{+} \\
& \mathrm{nAl}(\mathrm{OH})_{3} \rightarrow \mathrm{Al}_{\mathrm{n}}(\mathrm{OH})_{3 \mathrm{n}} \\
& \mathrm{Ksp} \mathrm{Al}(\mathrm{OH})_{3}=\left[\mathrm{Al}^{3+}\right]\left[\mathrm{OH}^{-}\right]^{3}=10^{-31.6}
\end{aligned}
$$

Pengaturan $\mathrm{pH}$ sangat penting dalam proses elektrokoagulasi. Oleh karena itu optimasi terhadap $\mathrm{pH}$ dilakukan untuk mendapatkan \% penurunan kadar surfaktan yang tinggi dengan kadar aluminium yang rendah dalam larutan. Kadar aluminium yang tinggi di dalam larutan dapat menyebabkan pencemaran lingkungan Dari penelitian didapatkan hasil sebagai berikut: 
Untuk $\mathrm{Al}^{3+}=2.4 \cdot 10^{-7} \mathrm{~mol}$

Jika volum $=0.5 \mathrm{~L}$ maka $\left[\mathrm{Al}^{3+}\right]=\frac{2.4 \cdot 10^{-7}}{0.5} M=$ $1.3 \cdot 10^{-5} \mathrm{M}$

Pada $\mathrm{pH}=7$ maka $\left[\mathrm{Al}^{3+}\right]\left[\mathrm{OH}^{-}\right]^{3}=$ $\left(1.3 \cdot 10^{-5}\right)\left(10^{-7}\right)^{3}=1.3 \cdot 10^{-26}$

Pada $\mathrm{pH}$ rendah terjadi netralisasi muatan spesi ionik SDS yang ada di air limbah oleh ion yang bermuatan berlawanan yang dihasilkan dari elektrokimia elektroda anoda yaitu $\mathrm{Al}(\mathrm{OH})^{2+}$, $\mathrm{Al}(\mathrm{OH})_{2}{ }^{+}$. Ion yang berlawanan ini mengurangi tolak menolak elektrostatik antar partikel sehingga gaya van der Waals menjadi dominan, hal ini menyebabkan terjadi koagulasi. Pada elektrokoagulasi dengan $\mathrm{pH}$ awal 2, $\mathrm{pH}$ berangsur - angsur naik menjadi pH 4 di menit ke 5 dan bertahan sampai akhir elektrolisis. Begitu juga dengan elektrokoagulasi pada $\mathrm{pH}$ awal $4, \mathrm{pH}$ meningkat menjadi 5 di menit ke 15 dan menjadi pH 6 di menit ke 45 dan bertahan sampai akhir elektrolisis. Peningkatan $\mathrm{pH}$ selama elektrolisis disebabkan oleh reduksi air di katoda menghasilkan $\mathrm{OH}^{-}$, sesuai dengan reaksi:

$$
2 \mathrm{H}_{2} \mathrm{O}+2 \mathrm{e} \rightarrow \mathrm{H}_{2}+2 \mathrm{OH}^{-}
$$

Meningkatnya $\mathrm{pH}$ selama elektrokoagulasi mendekati daerah netral yang memiliki solubiliti yang rendah memungkinkan terbentuknya $\mathrm{Al}(\mathrm{OH})_{3}$ sehingga terjadi sweep coagulation dimana terjadi penangkapan koloid negatif dan ikut mengendap saat hidroksida logam tersebut terbentuk. Pada $\mathrm{pH}$ tinggi, terbentuk $\mathrm{Al}(\mathrm{OH})_{4}{ }^{-}$ yang tidak efektif dalam koagulasi. Sehingga pada daerah ini, \% penurunan kadar surfaktan SDS rendah dan kadar aluminium tinggi di dalam larutan.

\section{Pengaruh penambahan elektrolit garam terhadap efektivitas elektrokoagulasi surfaktan anionik}

Elektrolit adalah larutan yang dapat menghantarkan listrik. Konduktivitas adalah kemampuan material untuk menghantarkan arus listrik. Semua senyawa ionik adalah elektrolit kuat. Mereka penghantar arus listrik yang sangat baik karena memiliki suplai ion yang banyak di larutan. Beberapa senyawa kovalen polar juga termasuk elektrolit kuat.

Tujuan ditambahkan elektrolit adalah untuk meningkatkan konduktivitas larutan, sehingga dapat menghemat konsumsi energi. Selain itu elektrolit dapat memperkecil kelarutan sehingga mempercepat proses koagulasi.

Untuk mengetahui pengaruh penambahan elektrolit garam pada efektivitas elektrokoagulasi SDS, dipilih elektrolit $\mathrm{NaCl}$ dan $\mathrm{Na}_{2} \mathrm{SO}_{4}$. Kedua elektrolit tersebut dibandingkan dengan total ionik yang sama di dalam larutan yaitu $1.7 \times 10^{-2}$ M. Serta dibandingkan dengan tanpa penambahan elektrolit garam. Dari percobaan didapat hasil sebagai berikut:

Tabel. 2. Hasil \% penurunan kadar surfaktan pada variasi penambahan elektrolit garam

\begin{tabular}{ccccccccc}
\hline Elektrolit & \multicolumn{2}{c}{$\mathrm{pH}$} & \multicolumn{2}{c}{$\begin{array}{c}\text { Konduktivitas } \\
(\mu \mathrm{S})\end{array}$} & $\begin{array}{c}\text { Konsumsi } \\
\text { energi }\end{array}$ & MBAS (mg/L) & $\begin{array}{c}\text { \% penurunan } \\
\text { kadar SDS }\end{array}$ \\
& awal & akhir & awal & akhir & $\begin{array}{c}\text { (kWh/kg } \\
\text { SDS) }\end{array}$ & awal & akhir & \\
\hline Tanpa & 4 & 6 & 330 & 320 & 16,5 & 200 & 11,91 & 94,04 \\
$\mathrm{NaCl}$ & 4 & 6 & 350 & 320 & 7 & 200 & 56,73 & 71,63 \\
$\mathrm{Na}_{2} \mathrm{SO}_{4}$ & 4 & 6 & 420 & 400 & 3,5 & 200 & 70,23 & 64,88 \\
\hline
\end{tabular}

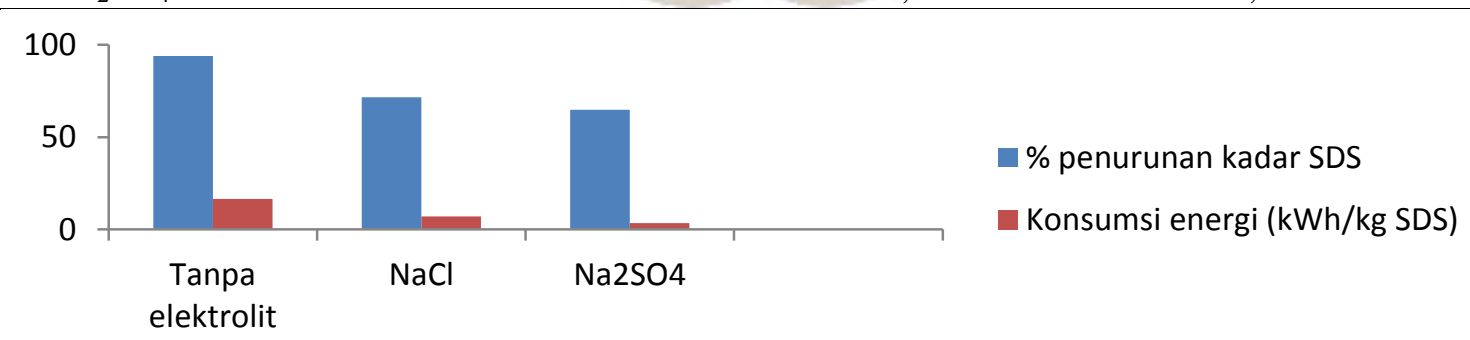

Gambar. 2. Pengaruh penambahan elektrolit garam terhadap terhadap $\%$ penurunan kadar surfaktan anionik SDS. (Kondisi operasional: konsentrasi SDS $200 \mathrm{mgL}^{-1}$, pH awal 4, waktu elektrolisis 60 menit, kerapatan arus $50 \mathrm{~A} / \mathrm{m}^{2}$ ) 
Di dalam larutan, $\mathrm{NaCl}$ akan menghasilkan ion $\mathrm{Na}^{+}$dan $\mathrm{Cl}^{-}$sesuai dengan reaksi:

$\mathrm{NaCl}_{(\mathrm{aq})} \rightarrow \mathrm{Na}^{+}{ }_{(\mathrm{aq})}+\mathrm{Cl}_{\text {(aq) }}^{-}$

Sedangkan $\mathrm{Na}_{2} \mathrm{SO}_{4}$ menghasilkan $2 \mathrm{Na}^{+}$dan $\mathrm{SO}_{4}{ }^{2-}$ sesuai dengan reaksi:

$\mathrm{Na}_{2} \mathrm{SO}_{4(\text { aq) }} \rightarrow 2 \mathrm{Na}^{+}{ }_{(\text {aq })}+\mathrm{SO}_{4}{ }^{2-}{ }_{(\text {aq) }}(6)$

Arus listrik dibawa melalui larutan oleh ion $\mathrm{Na}^{+}$ ke elektroda negatif dan ke elektroda positif oleh ion $\mathrm{Cl}^{-}$, begitu juga dengan $\mathrm{Na}_{2} \mathrm{SO}_{4}$.

Dari data didapatkan konsumsi energi $\mathrm{Na}_{2} \mathrm{SO}_{4}$ setengah dari $\mathrm{NaCl}$. Pada kondisi pengukuran yang sama, $\mathrm{NaCl}$ yang termasuk elektrolit 1:1 (senyawa yang terdiri dari ion +1 dan ion -1) dapat menghantarkan arus setengah dari $\mathrm{Na}_{2} \mathrm{SO}_{4}$ yang termasuk elektrolit 1:2. Hal ini disebabkan oleh ion $\mathrm{Na}^{+}$di dalam larutan $\mathrm{Na}_{2} \mathrm{SO}_{4}$ dua kali lebih banyak dari pada di dalam larutan $\mathrm{NaCl}$ dan ion $\mathrm{SO}_{4}{ }^{2-}$ yang bermuatan dua akan menghantarkan arus dua kali lebih banyak dari ion $\mathrm{Cl}^{-}$pada kecepatan yang sama.

Walaupun larutan $\mathrm{Na}_{2} \mathrm{SO}_{4}$ menghasilkan konsumsi energi yang paling kecil, namun dari data didapatkan elektrokoagulasi tanpa penambahan elektrolit garam menghasilkan \% penurunan kadar SDS yang lebih tinggi dibandingkan dengan elektrolit $\mathrm{NaCl}$ dan $\mathrm{Na}_{2} \mathrm{SO}_{4}$. Hal ini kemungkinan disebabkan oleh terjadinya peptisasi, yaitu pelarutan kembali flok yang terbentuk karena konsentrasi elektrolit yang berlebih. Oleh karena itu dilakukan optimasi konsentrasi $\mathrm{NaCl}$. Didapat hasil sebagai berikut:

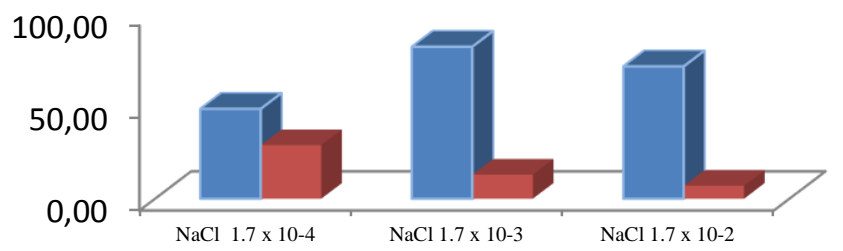

konsumsi energi (kWh/kg SDS)

Gambar. 3. Pengaruh konsentrasi $\mathrm{NaCl}$ terhadap \% penurunan kadar surfaktan anionik SDS. (Kondisi operasional: konsentrasi SDS $200 \mathrm{mgL}^{-1}$, $\mathrm{pH}$ awal 4, waktu elektrolisis 60 menit, kerapatan arus $50 \mathrm{~A} / \mathrm{m}^{2}$ )

Konsentrasi $1 \times 10^{-3}$ M memberikan \% penurunan kadar SDS yang lebih tinggi dibandingkan $1 \times 10^{-2} \mathrm{M}$. Tetapi masih rendah dibandingkan tanpa penambahan elektrolit garam. Konduktivitas larutan tanpa penambahan elektrolit garam sama dengan konduktivitas larutan dengan penambahan elektrolit $\mathrm{NaCl}$. Hal ini disebabkan oleh penambahan $\mathrm{HCl}$ selain untuk pengaturan $\mathrm{pH}$ awal larutan sampel juga berperan sebagai elektrolit kuat sehingga menyebabkan konduktivitas larutan meningkat. Oleh karena itu, penambahan elektrolit garam tidak dibutuhkan dalam proses elektrokoagulasi jika pada proses tersebut menggunakan asam kuat untuk mengatur $\mathrm{pH}$ awal larutan sampel.

\section{KESIMPULAN}

Pengolahan limbah surfaktan dengan elektrokoagulasi efektif pada $\mathrm{pH}$ awal 4 dan tanpa penambahan elektrolit garam dengan \% penurunan kadar surfaktan sebesar 94,04\% .

\section{DAFTAR PUSTAKA}

Alaton, I.A., Kabdasli I., dan Sahin, Y. (2008): Effect of Operating Parameters on the Electrocoagulation of Simulated Acid Dyebath Effluent, Open Environ. Biol. Monit. J. 1, 1-7

Kashefialasl, M., Khosravi, M., Marandi, R., dan Seyyedi, K. (2006): Treatment of dye solution containing colored index acid yellow 36 by electrocoagulation using iron electrodes, Int. J. Environ. Sci. Technol. Vol. 2, No. 4, 365-371

Kobya, M., Can, O.T., dan Bayramoglu, M., (2003): Treatment of textile wastewaters byelectrocoagulation using iron andaluminum electrodes, J. Hazard. Mater. B100, 163-178

Maghanga, J.K., Segor, F.K., Etiégni, L., dan Lusweti, J. (2009): Electrocoagulation method for colour removal in tea effluent: a case study of chemoni tea factory in rift 
valley, Bull. Chem. Soc. Ethiop, 23(3), 371-381

Mohta, A. (2007): Electro-chemical Treatment of Wastewater, Master of Technology Disertation, Thapar University, 21 - 22.

Mollah, M.Y.A., Schennach, R., Parga, J.R., dan Cocke, D.L. (2001): Electrocoagulation (EC) - science and applications, J. Hazard. Mater. 84, 29-41

Mollah, M.Y.A., Morkovsky, P., Gomes, J.A.G. Kesmez, M., Parga, J., dan Cocke, D.L. (2004): Fundamentals, present and future perspectives of electrocoagulation, $J$. Hazard. Mater. 114, 199-210

Mollah, M.Y.A., Gomes, J.A.G., Das, K.K., dan Cocke, D.L. (2010): Electrochemical treatment of Orange II dye solution-Use of aluminum sacrificial electrodes and floc characterization, J. Hazard. Mater. 174, 851-858

Prabhakari, D., Basha, C.A., Kannadasan T., dan Aravinthan P. (2010): Removal of hydroquinone from water by electrocoagulation using flow cell and optimization by response surface methodology. J. Environ. Sci. Health., Part $A, \mathbf{4 5}, 400-412$

SNI 06-6989.34-2005. Air dan Air Limbahbagian 34: Cara Uji Kadar Aluminium (Al) dengan Spektrofotometer Serapan Atom.

SNI 06-6989.51-2005. Air dan Air Limbahbagian 51: Cara Uji Kadar Surfaktan Anionik dengan Spektrofotometer Secara Biru Metilen.

Timmes, T.C., Chul Kim, H., dan Dempsey, B.A. (2009): Electrocoagulation pretreatment of seawater prior to ultrafiltration: Benchscale applications for military water purification systems, Desalination, 249, 895-901

Vasudevan, S., Jayaraj, J., Lakshmi, J., dan Sozh, G. (2009): Removal of iron from drinking water by electrocoagulation: Adsorption and kinetics studies, Korean J. Chem. Eng., 26(4), 1058-1064 